\title{
Informar del miedo, informar con miedo
}

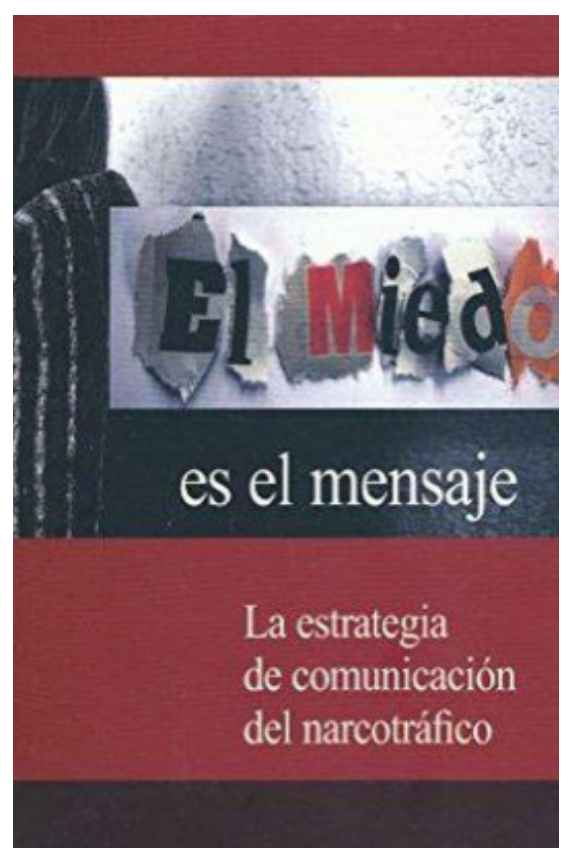

\section{El miedo es el mensaje. La estrategia de comunicación del narcotráfico}

Javier H. Contreras O.

Instituto Chihuahuense de la

CulturaMAPorrúa, México, 2017

286 páginas

Reseña por Itzel Yareli Meza-Piña

El pueblo mexicano se encuentra sumergido en un fenómeno social de narcotráfico, posicionándolo como uno de los países más peligrosos del mundo, y a su vez relacionándolo con temas de violencia a través de los medios de comunicación.

Tomando en cuenta a la agenda setting donde los medios juegan un poderoso control social no diciendo lo que no hay que pensar, sino en que debemos pensar. Estableciendo los temas de discusión pública.

El mundo de los medios de comunicación domina a los lectores con imágenes que provocan intriga, aquellas que van acompañadas de morbo, tragedia y en relación a la muerte o miedo tal como lo presenta Javier $\mathrm{H}$. Contreras, el autor de este libro El miedo es el mensaje al tocar temas relacionados con la estrategia de comunicación del narcotráfico.

El autor comparte además opiniones con el catedrático Ramón Reig, al afirmar que los seres humanos quedan ante el instinto y ante la imagen mediática como un nuevo asombro, el nuevo espectáculo. 
Ejercer la profesión periodística en México es un riesgo que no muchos están dispuestos a tomar. No es una tarea sencilla y menos cuando los miembros de los organizaciones criminales intervienen diseñando estrategias de comunicación por medio de los periódicos y televisión dirigidos a los grupos rivales, al gobierno y a la comunidad.

En esta obra, se trata a dos elementos principales: el lenguaje y la violencia. El primer término que funciona como una herramienta para los medios de comunicación y al mismo tiempo como una fuente de poder que llega hasta el público receptor. En el caso del narcotráfico, se ha creado un gran número de palabras que utilizan como clave entre ellos, como ejemplo encontramos la creación de los ya famosos narcocorridos, que hacen alusión a sus hazañas, identificando a los personajes, sus territorios, sus propiedades y mujeres. Por otro lado, viene como acompañante la violencia, en un escenario de dramatización y espectacularidad ante el miedo, el asombro y la incertidumbre.

La violencia se encuentra fácilmente al alcance de la sociedad, generando interés del receptor, por medio de series televisivas, videojuegos, telenovelas, transmitida en forma de espectáculo para acaparar la atención de la sociedad.

Después de un largo proceso de investigación por parte del autor Javier Contreras, con bases bien fundamentadas aborda el papel del periodismo ante la violencia, con aportaciones interpretativas a partir de datos tangibles.

Partiendo de que la delincuencia consecuente del crimen organizado forma parte de la mercadotecnia y la economía de los cárteles de la droga es como la mafia de las empresas de poder. Aunque en un principio la idea era no llamar la atención, actualmente se trata de ser vistos y señalados para bien o para mal, simplemente les importa estar presentes. Es en donde entra el narcotráfico con su diseño de estrategia para decir que se publica y cómo, de acuerdo a los intereses que mejor les conviene. 